to express our opinion that the Brush lamp, per se, is the best, their system of illumination and distribution of posts cannot be compared with the care and skill evinced by the Messrs. Siemens. If either company were to try our suggestion, and illuminate down the centre of the street, maintaining the line of the street in their line of lights, we should have another interesting experiment that would go far to solve this question.

One last point deserves attention. It is the effect which these strong and powerful electric light currents have on the working of the telegraph. It was feared that their presence would deteriorate the working capacity of telegraph wires, and undoubtedly it would be so were it not that, taking advantage of the warnings given them, the electric light people have in all cases adopted a return wire, so as to make their circuit completely metallic throughout. We are glad to learn that this has proved quite effective except in one instance, where along London Bridge the return wire has been taken round the other side of the bridge, and here considerable disturbances have been experienced in certain telephone circuits from the contiguity of the electric light currents. No other disturbance has as yet been experienced.

We have also as yet to experience the effect of weather. Up to the present moment it has been all in favour of the electric light-bright, clear, cheerful skies have given to the light a clearness and brilliancy that have created for it a strong feeling. When thick weather and rain and fog occur there may be a change in this opinion, not only from a disturbance of the penetrating power of the light, but on the effect of rain and moisture on the wires conveying the currents.

( $T o$ be continued.)

\section{DR. HOLUB'S AFRICAN TRAVELS}

I.

FROM his boyhood days Emil Holub determined he would explore some of the out-of-the-way portions of the African continent, and in 1872 the opportunity was presented to him of travelling in the southern parts of that great and still unexplored country. The result of seven years labour, during which period of time he made three several journeys of investigation, are now in these volumes laid before the public. In Dr. Holub's first journey he started from Port Elizabeth, crossing the Cape Colony district and the extreme south-west corner of the Orange Free State, to Kimberley. As far as Grahamstown he could have had the modern convenience of a train, but preferred a two-wheeled cart drawn by four small horses, making about eight miles an hour. The country is very charming for the greater part of this route, the road being beneath the brow of the Zuur Mountains, which with their wooded clefts and valleys, and their little lakes inclosed by sloping pastures, afforded many interesting views. The fauna was as varied as the flora, and numerous captures were made by the way. Even large game like elephants were to be met with, and the author records a sad accident which happened in the underwood by the Zondago River, between Port Elizabeth and Grahamstown. A black servant sent to look for some strayed cattle had been met by a herd of passing elephants, some of whom knocked him down and then trampled him to death. In this district these big animals are under the protection of the Government, and not being often interfered with, they would seem to have no great fear of man. The springbok (Antelope euchore) is noticed as still in some districts swarming, though its numbers must be rapidly diminish-

I "Seven Years in South Africa. Travels, Researches, and Hunting Adventures between the Diamond Fields and the Zambesi." By Dr. Emil Holub (translated by Ellen E. Frewer). With about 200 original illustrations and a map. In two volumes. (London: Sampson Low, Marston, Searle, and Rivington, $188 \mathrm{r}$.) ing, as Dr. Holub saw whole waggon-loads brought to Kimberley, where the carcases were sold at prices varying from three to seven shillings a head. Among other wonderful instances given of the great skill of the Dutch Boers in bringing down these swift creatures, he tells of one expert marksman killing by a single shot from his breech-loading rifle two of these antelopes.

Towards Colesberg the country forms a high tableland; it is on an affluent of the Orange River. On this table-land there was a herd of upwards of fifty quaggas, the only herd the author could hear of in South Africa. The farmers have lately spared them, so that during the last ten years they had increased to their present number from a small herd of fifteen. Philippolis, the first town entered of the Orange Free State, is described as dreary-looking, the houses mostly unoccupied, and the general aspect most melancholy. On the way to the Diamond Fields nothing but bad roads and worse weather were encountered; the wind was piercing, and snow actually fell. Fauresmith, one of the most considerable towns in the republic, although consisting of not more than eighty houses, covered a considerable area. It was clean and pleasant-looking, and here the author thought of settling for a time, and by the practice of his profession saving enough of money to enable him to start afresh for other fields; but the fates were against him, and he was, after a few days, obliged to push on to the Diamond Fields, and the following extract will best tell of these :-

"The first day upon which I set my eyes upon the Diamond Fields will ever be engraved on my memory. As our vehicle made its rapid descent from the heights near Scholze's Farm, and when my companion, pointing out to me the bare plains just ahead, told me that there lay my future home, my heart sank within me. A dull dense fog was all I could distinguish. A bitter wind rushing from the hills, and howling around us in the exposure of our open waggon, seemed to mock at the protection of our outside coats, and seemed resolved to make us know how ungenial the temperature of winter in South Africa could be ; and the grey clouds that obscured the sky shadowed the entire landscape with an aspect of the deepest melancholy. Yes; here I was approaching the Eldorado of the thousands of all nations, attracted hither by the hope of rich reward; but the nearer I came the more my spirit failed me, and I was conscious of a sickening depression. Immediate contact with the fog that had been observed from the distant heights at once revealed its true origin and character. It proved to be dense clouds of dust first raised by the west wind from the orange-coloured sand on the plains, and then mingled with the loose particles of calciferous earth piled up in heaps amidst the huts on the diggings. So completely did it fill the atmosphere that it would require little stretch of imagination to fancy that it was a sand-storm of the Sahara. As we entered the encampment the blinding dust was so thick that we could only see a few yards before us; we were obliged to proceed very cautiously, and before we reached the office of the friend I had to call on, another mile or so farther on, our faces and our clothes were literally incrusted. We only shared the fate of all new-comers in feeling not only distressed but really ill; the very horses sneezed and snorted, and showed that the condition of things was no less painful to them than to their masters. Here and there on both sides, right and left, wherever the gloom would permit me to see, I noticed round and oblong tents and huts intended for shops, but now closed, built of corrugated iron. Under the fury of the wind the tent-poles bent, and the ropes were subjected to so great a strain that the erections threatened every moment to collapse. Many and many a sheet of the galvanised iron got loose from the roofs or sides of the huts, and creaking in melancholy discord, contributed as it were to the gloominess of 
the surroundings. In many places too the pegs that had fastened the tents to the ground had yielded to the pressure, and sheets of canvas were flapping in the air like flags of distress. Truly it was a dreary scene, and I sighed at my dreary prospect."

Here Dr. Holub spent some months, making but one excursion at Christmas time (1872) just within the border of the Free State, to enjoy a little fresh air and have a shot at the baboous. In this portion of his work he gives a very interesting account of the diamond workings at Kimberley, and of the motley crew of workers that he met. Some views of the Kimberley Kopje as it appeared in 187 I are given, one of which (Fig. I) will give our readers some idea of the dreary aspect of a "diamond quarry." His medical practice increased so rapidly that by the end of January, 1873, he was enabled to purchase a waggon and a good many of the requisites for travel, and early in February he actually started out on his first long journey of exploration, which, however, he from the first only regarded as one of reconnaissance, with the object of getting in part acclimatised to live in the open air, and to acquire by actual experience a knowledge of what would

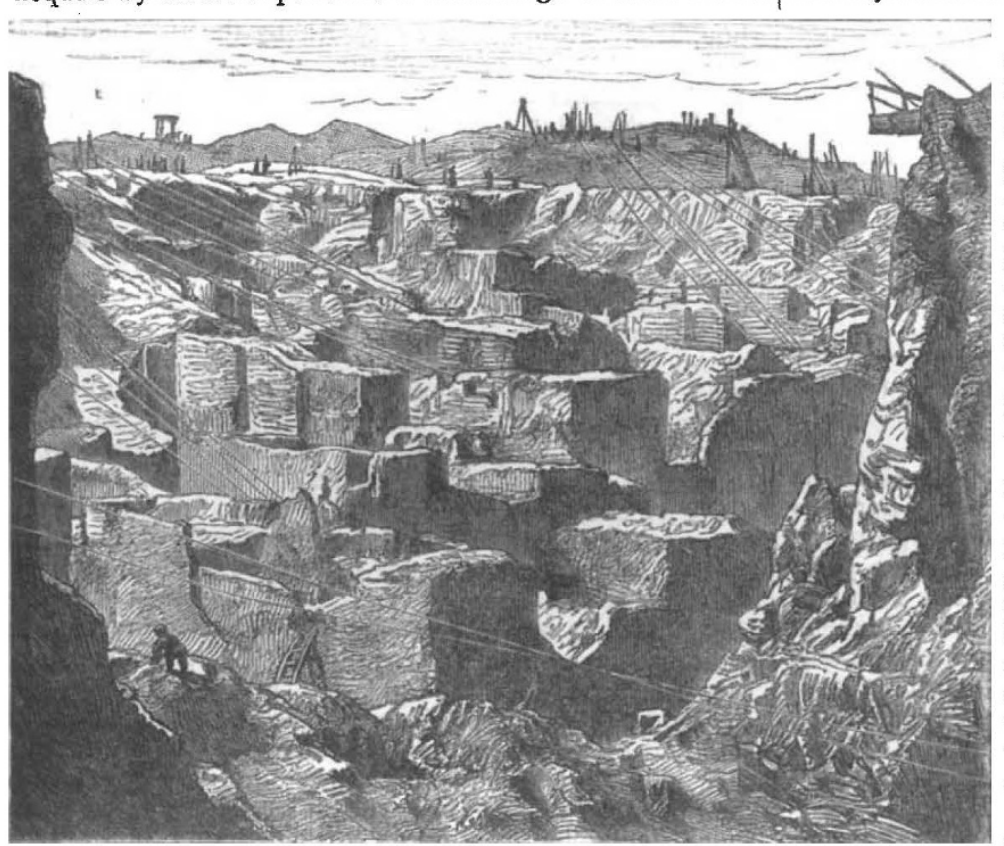

FIG. 1.

be necessary for a prolonged journey into the interior. The first village passed through was Pniel, a German missionary station among the Koranna. With the exception perhaps of the Matabele, no native tribe appeared to have been so little influenced by missionary labour. Their culture is of the very lowest grade. Of all the South African races the Koranna bestow the least labour upon the structure and the least care upon the internal arrangements of their dwellings. Their huts (Fig. 2) consist of a bundle of branches about six feet in length, the upper ends tied together, the lower arranged in a circle, some rush-mats thrown over this hasty framework, in which an aperture is left large enough to admit a human being on all fours. A hollow dug out in the centre is the only fireplace. Scarcely anything worthy of the name of agriculture is carried on, and their chief care is devoted to their corn and goats. Lazy, dirty, untruthful, living without a thought beyond the present, capable of any crime for the sake of drink, it seems no great pity that the tribe is dying out. Crossing the Vaal River, Klipdrift was reached; in the district between the Vaal and Harts Rivers herds of the striped grey gnu
(Catoblepas gorgon) were to be seen. The roads were here no better than the channels of boulder streams. Formerly both shores of the lower part of the Harts River were in the possession of Yantje, the Batlapin chief, who is a dependant of the British with an income of $200 l$. a year. This chief now resides at Likatlong. The Batlapins are mostly of middle height, not so tall as the Zulus' nor so powerfully built as the Fingos. Their complexions are bright and clear; they have very wide noses.

The sugar-cane was cultivated here and there, but the only use made of it was the chewing the more juicy portions of the stem. After Klipdrift, Bloemhof was visited ; then the Maquassie River was crossed, and a few days were spent at Klipspruit, which would seem to be quite a paradise for the sportsman; the early morning hours never failed to exhibit many herds of gnus and antelopes. The bushes were the baunt of the guinea fowl. This breed of wild fowl is one of great interest; though hunted perpetually, it would appear to be still on the increase; most frequently it is found in flocks of from ten to forty in number.

Arriving at Wonderfontein, the underground fissures, sometimes several miles long, were examined. One fine cave, known as the "Grotto of Wonderfontein," was partially explored; a little brook rippled through it, and it was thickly inhabited by bats. After much enjoyment of the natural objects associated with this place, Dr. Holub determined to end here his first excursion, and from thence to make his way back to Dutoitspan; slightly altering his track back, he broke somewhat new ground. Here is a short account of an encounter with a mass of feathered life :-

"The bank on which we crouched was the boundary of a depression overgrown with grass and reeds, but now full of rain-water. In this pool were birds congregated in numbers almost beyond what could be conceived - birds swimming, birds diving, birds wading. Perhaps the most conspicuous were the sacred ibises, of which there would not have been less than fifty, some of them standing asleep with their heads under their wings, some of them striding about solemnly, pausing every now and then to make a snap at a smaller victim, and some of them hurrying to and fro, dipping their bills below the water in search of fish. On thefar side, as if utterly oblivious of the world, a pair of grey herons stood pensive and motionless. From amongst the weeds, rose the unabated cackle of wild ducks, grey and speckled. Mingling with this were the deep notes of the countless moorhens, while an aspect of perpetual activity was given to the pond by the nimble movements of swarms of little divers. At a spot where the bank descended somewhat sharply to the edge of the pool several ruffs were wandering backwards and forwards, uttering their peculiar shrill whistle, and large flocks of sandpipers were to be noticed, either skimming from margin to margin of the water or resting passively just where they had alighted. The explanation of this enormous concourse of the feathered tribe was very simple. A storm of unwonted violence had washed down from the plain above into the hollow beneath myriads of worms, insects, lizards, and even mice, and so bountiful a banquet had attracted the promiscuous and immense gathering which had excited my wonder."

The second excursion was begun under somewhat better auspices, but it was only contemplated to journey over half the distance between the Diamond Fields and 
the Zambesi. The expedition started in November, 1873, with four Europeans, a waggon and eight oxen, with a Griqua driver, a saddle-horse, and nine dogs. From Dutoitspan it first went to Musemanyana, which is the most northerly possession of the Koranna king of Mamusa. On the north and east it is bounded by plains abounding in game, to which the author gave the name of the "Quagga flats." They belong to Montsua, and are the common hunting grounds of Batlapins, Barolongs, Korannas, and the Dutch farmers from the Western Transvaal. From Musemanyana they journeyed to Moshaneng. At Konana they found an immense abundance of game: gnus, blessbocks, hartebeests, springbocks, and zebras grazed in herds. A very interesting account is given of Molema's town : the sale of brandy is prohibited; European cereals have been introduced; two mission- aries were found here. Moshaneng is a Bechuana town, with a population of some 7000, many of whom have given up their heathen rites. Moloapolole was the next place visited. It was the residence of King Sechele, of whom we have lately heard a good deal. The number of his subjects was then estimated at about 35,000 , while resident but non-tributary tribes amounted to from 18,000 to 20,000 more.

Dr. Holub describes the king, somewhat harshly we think, as looking every inch a hypocrite. The king's house, furnished in European fashion, had cost him some $3000 \%$. He was the first of the six Bechuana kings to profess Christianity, but for all that he evidently is a believer in the doctrine that "the end justifies the means." Tea was served in cups; it was good, and the cakes unexceptionable; the sugar-basin, \&c., were all of silver.

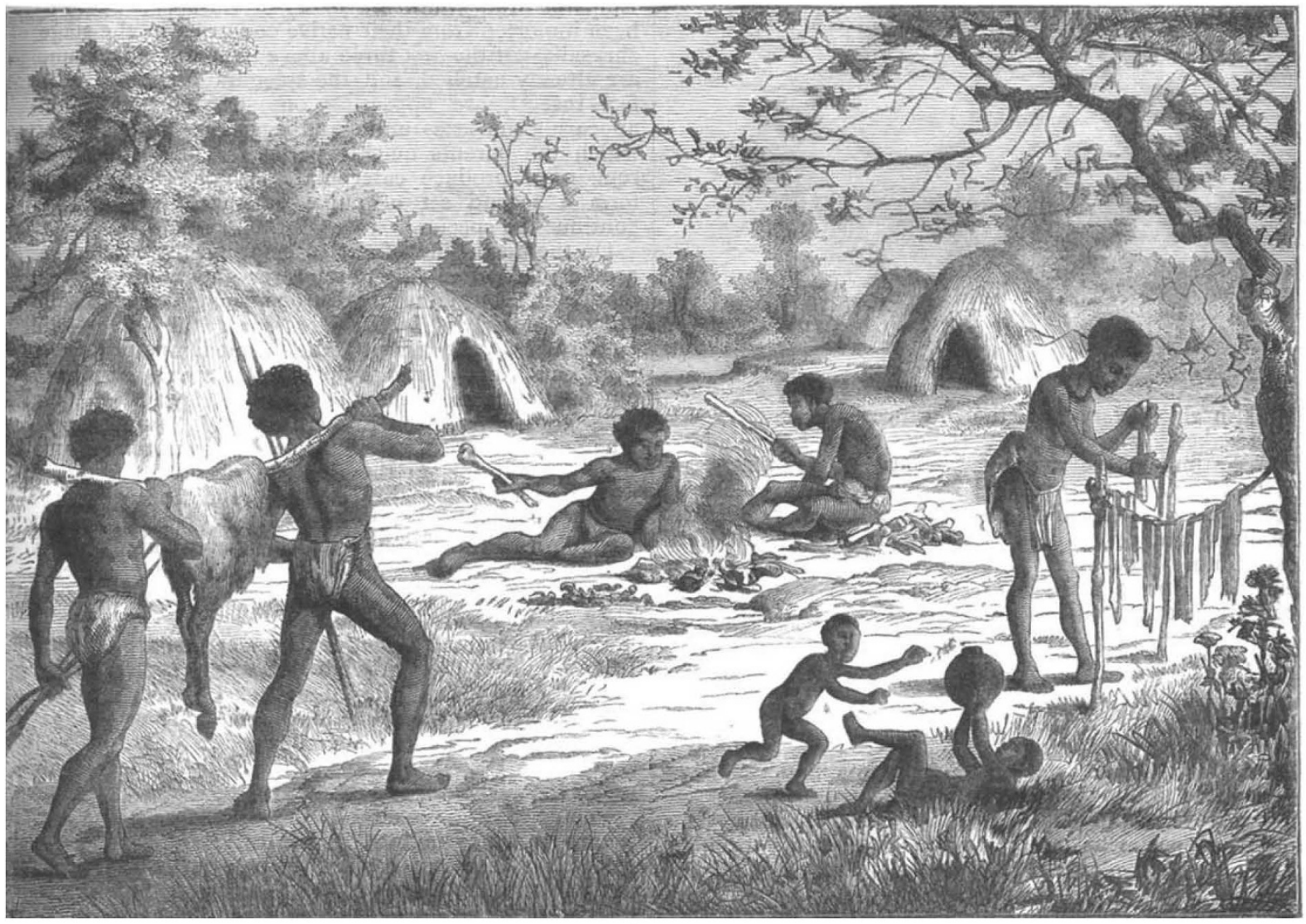

Fis. 2.

The king evidently enjoyed his tea, of which he swallowed nearly a quart. Addressing the king, Dr. Holub said: "When I was only thirteen years of age I read your name in Nyaka Livingstone's book. I little thought then that I should ever see you to speak to you; far more surprising is it to me to find myself drinking tea in your palace." The king, although still said to practise rain magic, replied sanctimoniously, "His ways are past finding out."

The Barwas and the Masarwas, although perhaps not really identical, are known by either name promiscuously amongst the Northern Bechuanas. They may be described as a cross between some branches of the Makalahari and the Bushmen. Their form, complexion, language, and customs afford various indications of their double origin. They are adepts at hunting, and are employed as hunters by their Bechuana masters. They use bows and arrows, and are very adroit in capturing animals by means of poisoned assegais. Their huts look something like large haycocks, consisting of a framework of stakes driven into the earth, fastened together firmly at the top, about five feet from the ground, and covered with a layer of twigs and dry grass. The Masarwas are of medium height, reddish-brown complexion, and a repulsive cast of countenance. They have a great aversion to agriculture and to cattle-breeding. They do not practise stone carving or use any stone utensils. They are very superstitious; treat their wives well, and show a great regard for their dogs. They pierce the nasal cartilage on reaching maturity; wear a body-cloth of hide. They suffer much from cold; but instead of lighting fires in their huts like the Korannas, regularly light these in the open air. The accompanying illustration shows these Masarwas at home.

From Molopole the route lay to Shoshong. This was 
the northern limit of this journey. It is the capital of the Eastern Bamangwatos, and the most important town in any of the independent native kingdoms in the interior of South Africa. It lies on the River Shoshon. The king's residence was built around the Kotla; the place has a circular space inclosed by a fence of strong stakes, the entrance being on the south side, opposite to which was an opening leading to another smaller inclosure, which was the king's cattle kraal, where his farm stock was kept at night, the horses being accommodated in the

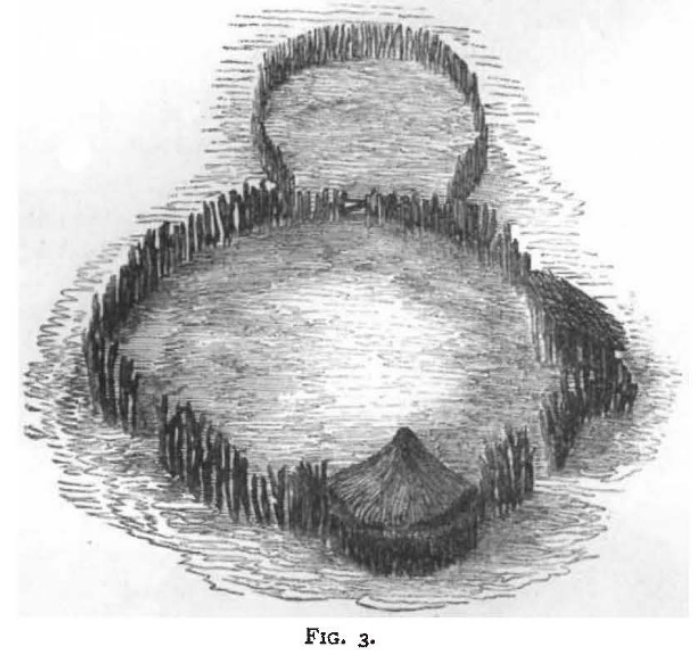

Kotla itself. Every night the entrances are made secure with stakes. Fig. 3 shows the king's kotla at Shoshong.

According to the missionary's (Mr. Mackenzie's) estimate, King Sekhomo's actual revenue was equivalent to about $3000 l$. a year, and consisted of cattle, ivory, ostrichfeathers, and skins; he had-happy man !-no state expenditure whatever. Dr. Holub's second expedition ended on April 7, when he arrived in safety with his large collections at Dutoitspan.

(To be continued.)

\section{THE NEW INSECT ARIUM IN}

THE ZOOLOGICAL SOCIETY'S GARDENS

A LTHOUGH of late years many entomologists have A been in the habit of rearing insects in captivity for the purpose of watching their transformations and obtaining good specimens in each stage of existence, nothing like a systematic attempt, so far as we know, has been made to form a general collection of living insects for exhibition. As in former days as regards reptiles and the lower marine animals, so in the present instance as regards its insectarium, our Zoological Society seems to be first in the field; and so far as we can judge from the progress already made, to be likely, if not altogether successful, to attain many interesting and instructive results.

The building in the Regent's Park Gardens now used as an insectarium is constructed of iron and glass on three sides, with a brick back to it, and formerly formed part of the refreshment buildings. It was moved to its present site, on the north bank of the canal near the north entrance, last autumn, and has been used during the winter as a nursery for delicate monkeys and tropical birds. The cases containing the insects, to which it is now devoted, are arranged on stands all round the building, and also occupy two tables in the centre. The cases used for the principal specimens are formed of zinc plates. The upper part of them is glazed on all four sides, the top being formed of perforated zinc so as to admit the air. The food-plant or object required for the suspension of the chrysalises, when that stage of the insect is exhibited, is inserted into the case through a circular hole in the bottom, but the glass front also opens, so that ready access may be obtained to the interior. The larger cases in the front row measure about 24 inches in breadth by 18 in depth, and are 32 inches in height. The cases in the opposite row are of similar construction, but rather smaller in dimensions.

The cases on the south side (on each side of the entrance door) are mostly appropriated to the exhibition of the larger and finer species of silk-producing moths of the family Bombycidæ. Amongst them may be specially noticed Glover's Silk-moth (Samia Glozeri) and the Cercopian Silk-moth ( $S$. cecropia) of North America, Perny's Silk-moth (Attacus Pernyi) of Northern China, the Tusseh Silk-moth (A. mylitta) of India, and the great Emperor Moth (Saturnia pyri) of Europe. These have been imported from their native countries in the stage of chrysalis. Of the first three above named, many examples are already hatched, and the splendid imagines, or perfect insects, are appearing one by one. Soon after appearing the sexes unite and eggs are produced, after which the parents quickly perish. The fertilised eggs remain to produce caterpillars, which will eventually form a second set of pupæ or chrysalises and thus continue the species.

On the north side of the Insectarium the smaller cases are devoted principally to the rarer and more noticeable moths and butterflies of Europe, such as the Swallowtailed Butterfly (Papilio machaon), the Black-veined Butterfly (Aporia cratagi), the Purple Emperor (Apatura iris), and the Orange-tip (Anthocharis cardamines) among the former, and the Scarlet Tiger Moth (Callimorpha dominula) and Emperor Moth (Saturnia carpini) among the latter group. The series is continued, mixed with other forms, at the east end of the building. On the large tables in the middle of the Insectarium are examples of other butterflies, moths, beetles, mayflies, stoneflies, and aquatic insects of different kinds, all well worthy of attention and study. The whole series exhibited now contains examples of about fifty species, but daily additions are made to it.

Finally we should mention that every specimen in the Insectarium is distinctly labelled, and that over each of the principal cases is fixed a glazed box, in which are placed preserved specimens of the various stages of metamorphosis of the insect exhibited in the case beneath.

Nor must we forget to add that the Insectarium is under the sole charge of Mr. E. Watkins, an experienced entomologist and breeder of insects, whose name is well known to many naturalists. Mr. Watkins, whose services have been secured for the Zoological Society for the purpose of inaugurating this interesting exhibition, is in daily attendance at the Insectarium, and is most ready and willing to afford information and instruction to all who apply to him.

\section{NOTES}

THE numerous friends and still more numerous admirers of Prof. Gegenbaur will be glad to hear that he is now believed to be out of danger. It appears that the illness of the distinguished anatomist commenced with an attack of erysipelas, the origin of which is not known; it does not seem that the case was complicated by any blood poisoning, but there was an attack of peritonitis, which caused the very greatest anxiety for some days. Lately however his condition has considerably improved, but it will, of course, be a long time before he can be completely restored to health.

AT the conversazione given to Prof. Helmholtz at University College, Mr. Latimer Clark exhibited the accompanying 